\title{
ASSEMBLAGE OF INSECTS ON MEDICINAL PLANTS: AN INSIGHT FROM ICIMOD HERBAL GARDEN IN GODAVARI OF LALITPUR, NEPAL
}

\author{
Daya Ram Bhusal ${ }^{1 *}$, Sweta Shrestha ${ }^{1}$, Kishor Chandra Ghimire ${ }^{2}$ \\ ${ }^{l}$ Central Department of Zoology, Tribhuvan University, Kirtipur, Kathmandu, Nepal \\ ${ }^{2}$ Birendra Multiple Campus, Bharatpur Chitwan, Tribhuvan University \\ *Corresponding author: drbhusal@cdztu.edu.np
}

(Received: April 17, 2019; Revised: May 3, 2019; Accepted: May 10, 2019)

\begin{abstract}
Present study was conducted within the herbal garden of International Centre for Integrated Mountain Development (ICIMOD) in Godawari of Kathmandu valley to explore the insect communities in medicinal plants. Five medicinal plants, viz. Rauvolfia serpentina (= Sarpagandha), Urtica dioca (= Sissnu), Zanthoxylum armatum (= Timur), Valeriana jatamansii (= Sungandhawal) and Mentha spicata (= Pudina) were selected for the study. Insects were randomly sampled during four seasons from September 2017 to June 2018 using different collecting techniques, like hand picking, pit-fall traps, net-sweeping and stem beating. A total of 869 insects individuals belonging to 42 different genera were collected and identified. It was found that the abundance of insects was high during spring season (299 insects comprising $35 \%$ of collected species), followed by summer (255 insects comprising $29 \%$ of collected species) and winter (219 insects comprising $25 \%$ of collected species) seasons, and low during autumn season (96 insects comprising $11 \%$ of collected species). It was further found that the abundance of insect species was temperature-dependent, but was independent of relative humidity. The maximum indicator species were present on $M$. spicata. Taxonomic distinctness (delta+) of insects was high on $V$. jatamansii, but low on $U$. dioca.
\end{abstract}

Keywords: Insect pest, Diversity, Indicator species, Taxonomic distinctness, Physical parameters

\section{INTRODUCTION}

Nepal has globally significant and biologically diverse ecosystems that produce a wide range of unique and valuable medicinal plants and these plants have a significant role in the ancient ayurvedic medicine system. They can play a vital role in uplifting the local economy, health needs of people and improve the natural resource management and are also helpful in conserving the ecosystem and the authochthonous biodiversity of the area (Subedi 1997). However, the inventory of insects associated with the medicinal plants is vastly lacking in Nepal. There are many reports and sporadic researches regarding the pests of medicinal plants of Nepal, especially from the resources of plant protection (Gupta \& Bhusal 2018, Sharma et al. 2018). But the national-basis systematic studies on insects related to medicinal plants are poorly documented in terms of distribution, diversity and abundance. Similarly, the management of insect pests associated with medicinal plants is also poorly known in Nepal. In this context, the present study provides the basic information about the insect assemblage on selected five medicinal plants, viz. Rauvolfia serpentina (Sarpagandha), Urtica dioca (Sissnu), Zanthoxylum armatum (Timur), Valeriana jatamansii (Sungandhawal) and Mentha spicata (Pudina).

$R$. serpentina is an indigenous medicinal herb of Nepal having multiple influences on environment, biodiversity, rural economy, culture and health. It is also enlisted in Convention on International trade on endangered species of wild flora and fauna (CITES) Appendix II. On the other hand, $U$. dioca is an erect herbaceous plant which is distributed from tropical to subalpine regions of Nepal and is used as a diuretic agent to cure nephritis, haematuria, menorrhagia and could be used as juice source (Baral \& Kurmi 2006). Similarly, Z. armatum is a shrub or a small tree, commonly known as toothache tree or prickly tree, is also distributed from tropical to subalpine regions of Nepal. Root, bark, leaves, fruits and seeds of $Z$. armatum are used as paste and fruit powder (Baral \& Kurmi 2006). V. jatamansii is perennial erect herb distributed from subtropical to subalpine regions. It is bitter, laxative and is used as a cardio tonic. M. spicata is a small herb distributed in temperate region and is antiseptic, carminative, antispasmodic, stimulant and stomachic. Aerial part of the plant body is used as juice, infusion and essential oil (Baral \& Kurmi 2006). It is expected that the present study would provide baseline information to plan future research work in the field of medicinal plants in Nepal. Moreover, the results of this study will ultimately be helpful for the policy-makers to formulate sustainable plant protection policies especially focusing the medicinal plants.

\section{MATERIALS AND METHODS}

\section{Site description}

The study was carried out in Herbal Garden of ICIMOD knowledge park, Godawari, Lalitpur which lies in the southern part of Kathmandu valley $\left(27^{\circ} 35^{\prime} 57^{\prime \prime} \mathrm{N}\right.$ and $85^{\circ}$ $23^{\prime} 27^{\prime \prime}$ E). Different types of indigenous medicinal plants 
are found in the garden and only five major plants of $R$ serpentina, $U$. dioca, Z. armatum, V. jatamansii and $M$. spicata were selected for the present research work.

\section{Field design and insect collection}

A $20 \mathrm{~m} \times 20 \mathrm{~m}$ plot in each garden of selected plants was designed for sampling of the insects. Three replicating plots were laid randomly in the farm of each selected plant. Insect were collected once a week from 10 am to 3 pm. A pitfall trap (10 cm diameter) was applied for the collection of ground crawling insects. Insects were also collected by other techniques such as hand picking, sweeping net and stem beating. The insect was transferred to killing jar and was preserved using $70 \%$ alcohol. The ecological parameters like temperature and humidity of the sampling sites were recorded using thermohygrometer HTC-01. The photographs of the individual insects and their nature of damage were taken using Nikon Coolpix 18x Zoom in the field.

\section{Identification and preservation}

The each specimen was identified through suitable identification keys, morphological characters and taxonomy books (Hill 1993, Gillote 2005, David \& Ananthakrisnan 2006, Richards \& Davies 2013, Thapa 2015). The reference keys for identification were used from the published articles (Stubbs \& Falk 1983, Belskaya \& Kolesnikova 2011). The species were also morphologically compared with the identified specimen of Natural History Museum, Tribhuvan University, Kathmandu and some species were compared with the voucher specimens of Entomological Division of Nepal Agricultural Research Council (NARC) Khumaltar, Nepal. The collected specimens were deposited to Central Department of Zoology, Tribhuvan University, Kirtipur after completion of the study and they were preserved by carding and further following the staging using entomological pins.

\section{Data analysis}

The abundance and diversity data of identified insects was analyzed performing different statistical tool from " $R$ " statistical software, principal component analysis (PCA) taxonomic distinctness (delta+), diversity indexes and indicator species analysis (ISA) were carried.

\section{RESULTS}

Total 869 individuals of 7 orders, 27 families and 42 genera were identified in five medicinal plants as listed in Table 1.

\section{Indicator species analysis (ISA)}

The identification of species associated with or indicative of groups of samples is a common aspect of ecological research. Indicator species analysis (ISA) was calculated as suggested by Dufrene and Legendre (1997). The indicator species value ranged between 0 to 1(Table 2). Further, the insect species that were highly aggregated within the five different medicinal plants were observed by maximum classified analysis and found to be maximum in Mentha spicata.

\section{Principle component analysis (PCA)}

PCA was applied among genera to find the coleration by means of their frequency in the sampling plots. PCA analysis showed that there was positive as well as negative correlation in the PCA axis among the identified genera (Fig. 1). For example, Coccinella sp., Ourapteryx sp., Mythimna sp., Oenopia sp., Eristalis sp., Cerogria sp., Dodona sp., Paratetrix sp., Tetrix sp., Mononyx sp., halticus $\mathrm{sp}$. were high in abundance and positively correlated, whereas genera Catantops, Epilachna, Cazira, Hister, Leptocorisa showed low abundance. In two PCA axes (dimension) high variation, i.e., $36.31 \%$ in first axis, whereas $24.74 \%$ variations in second axis was exhibited as depicted in Fig. 1.

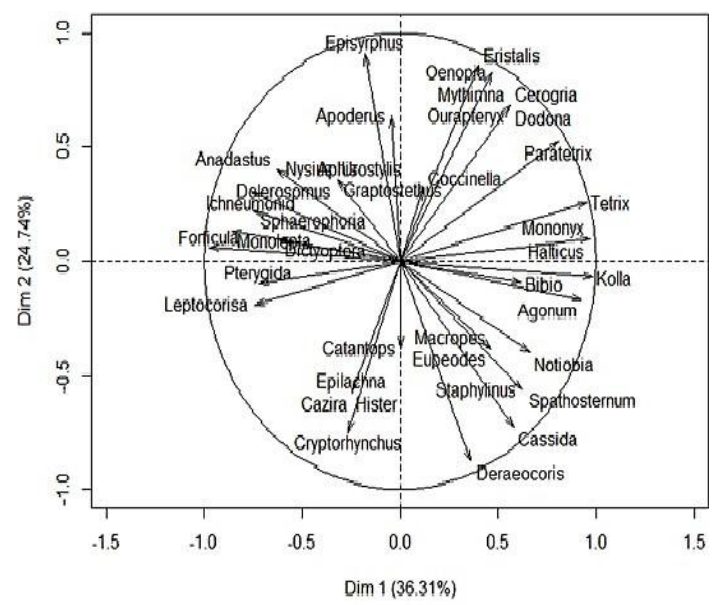

Fig. 1. Principle component analysis (PCA) based on frequency of genera associated with five medicianl plants

\section{Effect of seasons on insect abundance}

In this study, maximum insect collection was carried in spring season followed by summer and winter season (Fig. 2). The effect of seasons on abundance of insects was tested using generalized linear model (GLM). However, the relationship between relative humidity and temperature with insect frequency was tested statistically using linear regression model. The GLM was selected based on lowest AIC value in forward and backward selection of variables. The frequency was found to be significantly higher in autumn, winter and spring seasons, and the mean abundance of insect was least in summers without any statistical significance (Table 3). Further, the frequency of insects showed negative relation with relative humidity as well as significant regression with temperature (Table 4) as depicted in Fig. 3. 
Assemblage of insects on medicinal plants: an insight from ICIMOD herbal garden...

Table 1. Listing of insect genera and their presence absence within studied medicinal plants

\begin{tabular}{|c|c|c|c|c|c|}
\hline Genus & M. spicata & R. serpentina & U. dioca & V.jatamansi & Z. armatum \\
\hline Agonum sp. & + & - & - & + & - \\
\hline Anadastus sp. & - & - & - & - & + \\
\hline Aphid sp. & - & - & - & + & + \\
\hline Apoderus sp. & - & + & - & - & + \\
\hline Bibio sp. & + & + & + & + & - \\
\hline Cassida sp. & + & - & + & - & - \\
\hline Catantops sp. & + & - & - & - & + \\
\hline Cazirasp. & - & - & - & - & - \\
\hline Cerogria sp. & - & - & + & + & - \\
\hline Coccinella sp. & + & + & + & + & + \\
\hline Cryptorhynchus sp. & + & - & + & - & + \\
\hline Deraeocoris sp. & + & - & + & + & + \\
\hline Dictyoptera sp. & - & - & - & - & + \\
\hline Dodona sp. & - & - & - & + & - \\
\hline Dolerosomus sp. & - & + & - & - & - \\
\hline Epilachna sp. & - & - & + & - & - \\
\hline Episyrphus sp. & + & + & - & + & + \\
\hline Eristalis sp. & - & + & - & + & - \\
\hline Eupeodes sp. & + & + & - & - & - \\
\hline Forficula sp. & + & + & + & - & + \\
\hline Forficula sp. & - & + & + & + & + \\
\hline Forficula sp. & - & - & - & - & + \\
\hline Graptostethus sp. & - & + & - & - & - \\
\hline Halticus sp. & + & + & + & + & + \\
\hline Hister sp. & - & - & + & - & - \\
\hline Ichneumonid sp. & + & + & + & + & + \\
\hline Kolla sp. & + & + & + & + & + \\
\hline Leptocorisa sp. & - & - & + & - & + \\
\hline Macropes sp. & + & + & - & - & - \\
\hline Monolepta sp. & - & + & + & - & + \\
\hline Mononyx sp. & - & + & - & - & + \\
\hline Mythimna sp. & - & - & - & + & - \\
\hline Notiobia sp. & - & - & - & + & + \\
\hline Notobia sp. & - & + & - & - & - \\
\hline Nysius sp. & - & + & - & - & - \\
\hline Oenopia sp. & - & + & - & + & - \\
\hline Ourapteryx sp. & - & - & - & + & - \\
\hline Paratetrix sp. & + & + & - & + & + \\
\hline Pterygida sp. & - & - & + & - & + \\
\hline Spathosternum sp. & + & - & - & - & - \\
\hline Sphaerophoria sp. & - & + & - & - & + \\
\hline Staphylinus sp. & + & - & - & - & - \\
\hline Tetrix sp. & + & + & + & + & - \\
\hline Urostylis sp. & - & + & - & - & - \\
\hline
\end{tabular}


Table 2. Indicator Species analysis (ISA) of insect genera for medicinal plants (Rauvolfia serpentina (SER), Urtica dioca (DIO), Zanthoxylum armatum (ARM), Valeriana jatamansii (JAT) and Mentha spicata (SPI)

\begin{tabular}{|c|c|c|c|c|c|c|c|}
\hline \multirow{2}{*}{ S. No. } & \multirow{2}{*}{ Insect genera } & \multicolumn{5}{|c|}{ Indicator value of each genera for host plants } & \multirow{2}{*}{$\begin{array}{l}\text { Maximum } \\
\text { classified }\end{array}$} \\
\hline & & SPI & SER & DIO & JAT & ARM & \\
\hline 1 & Agonum & 0.64 & 0.00 & 0.00 & 0.36 & 0.00 & SPI \\
\hline 2 & Anadastus & 0.00 & 0.67 & 0.00 & 0.00 & 0.33 & SER \\
\hline 3 & Aphis & 0.00 & 1.00 & 0.00 & 0.00 & 0.00 & SER \\
\hline 4 & Apoderus & 0.00 & 0.00 & 0.00 & 0.50 & 0.50 & JAT \\
\hline 5 & Bibio & 0.25 & 0.25 & 0.25 & 0.25 & 0.00 & SPI \\
\hline 6 & Cassida & 0.80 & 0.00 & 0.20 & 0.00 & 0.00 & SPI \\
\hline 7 & Catantops & 0.50 & 0.00 & 0.00 & 0.00 & 0.50 & SPI \\
\hline 8 & Cazira & 0.00 & 0.00 & 1.00 & 0.00 & 0.00 & DIO \\
\hline 9 & Cerogria & 0.00 & 0.00 & 0.00 & 1.00 & 0.00 & JAT \\
\hline 10 & Coccinella & 0.25 & 0.17 & 0.06 & 0.22 & 0.31 & ARM \\
\hline 11 & Cryptorhynchus & 0.17 & 0.00 & 0.67 & 0.00 & 0.17 & DIO \\
\hline 12 & Deraeocoris & 0.38 & 0.00 & 0.38 & 0.13 & 0.13 & SPI \\
\hline 13 & Dictyoptera & 0.00 & 0.00 & 0.00 & 0.00 & 1.00 & ARM \\
\hline 14 & Dodona & 0.00 & 0.00 & 0.00 & 1.00 & 0.00 & JAT \\
\hline 15 & Dolerosomus & 0.00 & 1.00 & 0.00 & 0.00 & 0.00 & SER \\
\hline 16 & Epilachna & 0.00 & 0.00 & 1.00 & 0.00 & 0.00 & DIO \\
\hline 17 & Episyrphus & 0.07 & 0.27 & 0.00 & 0.33 & 0.33 & JAT \\
\hline 18 & Eristalis & 0.00 & 0.33 & 0.00 & 0.67 & 0.00 & JAT \\
\hline 19 & Eupeodes & 0.67 & 0.33 & 0.00 & 0.00 & 0.00 & SPI \\
\hline 20 & Forficula & 0.03 & 0.34 & 0.24 & 0.03 & 0.34 & SER \\
\hline 21 & Graptostethus & 0.00 & 1.00 & 0.00 & 0.00 & 0.00 & SER \\
\hline 22 & Halticus & 0.33 & 0.11 & 0.11 & 0.33 & 0.11 & SPI \\
\hline 23 & Hister & 0.00 & 0.00 & 1.00 & 0.00 & 0.00 & DIO \\
\hline 24 & Ichneumonid & 0.09 & 0.18 & 0.18 & 0.18 & 0.36 & ARM \\
\hline 25 & Kolla & 0.38 & 0.06 & 0.17 & 0.38 & 0.02 & SPI \\
\hline 26 & Leptocorisa & 0.00 & 0.00 & 0.33 & 0.00 & 0.67 & ARM \\
\hline 27 & Macropes & 0.67 & 0.33 & 0.00 & 0.00 & 0.00 & SPI \\
\hline 28 & Monolepta & 0.00 & 0.25 & 0.13 & 0.00 & 0.63 & ARM \\
\hline 29 & Mononyx & 0.50 & 0.00 & 0.00 & 0.50 & 0.00 & SPI \\
\hline 30 & Mythimna & 0.00 & 0.00 & 0.00 & 1.00 & 0.00 & JAT \\
\hline 31 & Notiobia & 0.67 & 0.00 & 0.00 & 0.17 & 0.17 & SPI \\
\hline 32 & Nysius & 0.00 & 1.00 & 0.00 & 0.00 & 0.00 & SER \\
\hline 33 & Oenopia & 0.00 & 0.25 & 0.00 & 0.75 & 0.00 & JAT \\
\hline 34 & Ourapteryx & 0.00 & 0.00 & 0.00 & 1.00 & 0.00 & JAT \\
\hline 35 & Paratetrix & 0.30 & 0.20 & 0.00 & 0.40 & 0.10 & JAT \\
\hline 36 & Pterygida & 0.00 & 0.00 & 0.25 & 0.00 & 0.75 & ARM \\
\hline 37 & Spathosternum & 1.00 & 0.00 & 0.00 & 0.00 & 0.00 & SPI \\
\hline 38 & Sphaerophoria & 0.00 & 0.25 & 0.00 & 0.00 & 0.75 & ARM \\
\hline 39 & Staphylinus & 1.00 & 0.00 & 0.00 & 0.00 & 0.00 & SPI \\
\hline 40 & Tetrix & 0.36 & 0.07 & 0.07 & 0.50 & 0.00 & JAT \\
\hline 41 & Urostylis & 0.00 & 1.00 & 0.00 & 0.00 & 0.00 & SER \\
\hline
\end{tabular}




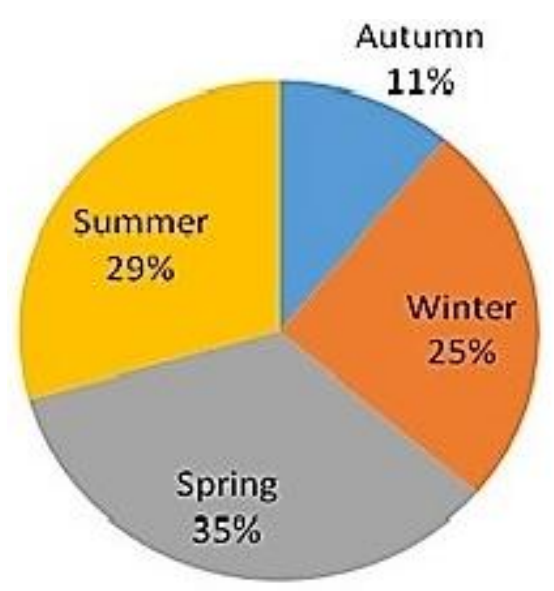

Fig. 2. The relative abundance of insects collected from five selected medicinal plants during four seasons from the study sites

a)

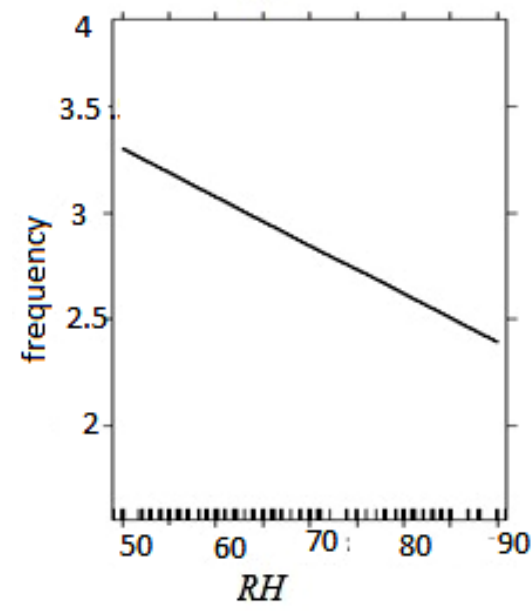

Table 3. Generalized linear model for the effect of four seasons on insect frequency

\begin{tabular}{lllll}
\hline Variables & Mean & stdE & Z-test & P Value \\
\hline Autumn & 1.8433 & 0.5613 & 3.284 & $\mathbf{0 . 0 0 1}$ \\
Spring & 1.0827 & 0.5423 & 1.996 & $\mathbf{0 . 0 4 6}$ \\
Summer & 0.4232 & 0.5394 & 0.785 & 0.433 \\
Winter & 1.6794 & 0.5969 & 2.814 & $\mathbf{0 . 0 0 5}$ \\
\hline
\end{tabular}

Table 4. Linear regression model for temperature and relative humidity with frequency of insects

\begin{tabular}{lllll}
\hline Variable & Mean & StdE & Z-test & P Value \\
\hline RH & -0.0228 & 0.0143 & -1.594 & 0.112 \\
Temp & -0.0784 & 0.0333 & -2.356 & $\mathbf{0 . 0 1 9}$ \\
\hline
\end{tabular}

b)

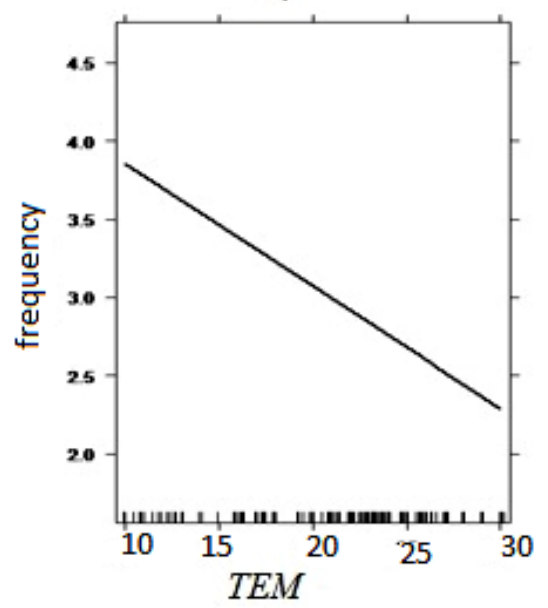

Fig. 3. Relation of insect frequency with a) RH (Relative humidity) and b) TEM (temperature)

\section{Diversity analysis}

The diversity of insects associated in five medicinal plants was performed based on Renyi diversity index (Fig. 4). High diversity status was observed in Rauvolfia serpentina (SER) respectively but low status was seen in Urtica dioca (DIO).

Taxonomic distinctness $($ delta +$)$ versus species number

Taxonomic distinctness (delta+) was calculated as suggested by Clarke and Warwick (1999). Taxonomic distinctness (Delta+) of insect genera was analyzed from five medicinal plants and was plotted against the species number of the samples. The $V$. jatamansii showed highest taxonomic distinctness. In contrast, the lowest taxonomic richness was shown by $U$. dioca. Further, $R$. serpentina showed highest species number but low taxonomic distinctness (Fig. 5).

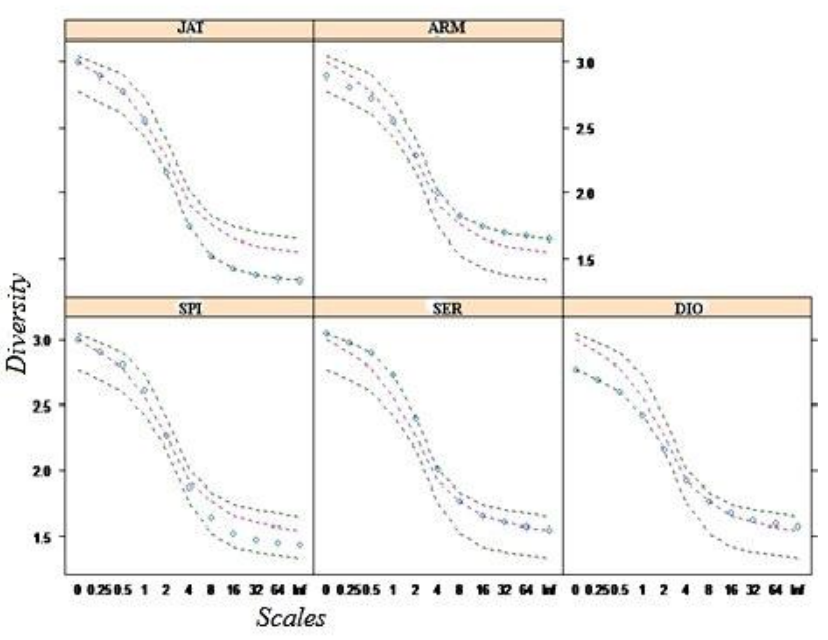

Fig. 4. Renyi diversity scales in five plants for insect communities 


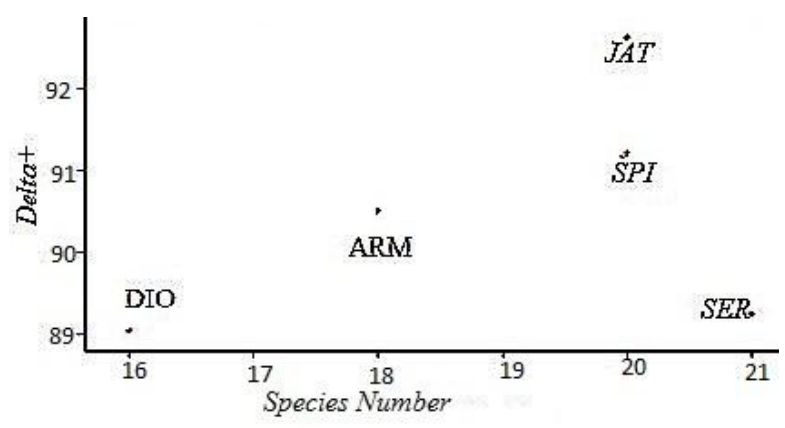

Fig. 5. Taxonomic distinctness (delta + ) vs. species number in five medicinal plants in our samples

\section{DISCUSSION}

Collection of 869 species under 7 orders, 27 families and 42 genera from the selected medicinal plants were made. Insect diversity was high during spring season (299 insects i.e. $35 \%$ of collected species), but low during autumn season (96 insect species, i.e. $11 \%$ of collected species). The diversity increased during spring and autumn seasons that attributed to favorable environmental conditions and abundant food resources for the herbivores groups. The present results were in conformity with Arya et al. (2016) who also concluded maximum richness, highest abundance and huge diversity of insects in medicinal plants during rainy season, followed by summer and winter seasons. In contrast, Balakrishnan et al. (2014) concluded that diversity index and species richness were higher in pre-monsoon season than in summer season. The inverse Simpson and evenness index was highest for $R$. serpentina and lowest for $V$. jatamansii, as reported earlier by Najar and Bashir (2016). Insects were found maximum on Valeriana jatamansii and minimum on $U$. dioca. The frequency of Kolla species (Family Cicadellidae) was found highest on all medicinal plants, probably owing to its defoliating behaviour.

Taxonomic distinctness (delta+) of insects was high in $V$. jatamansii but low in $U$. dioca. Similarly, $R$. serpentina had high species number whereas low taxonomic distinctness. The diversity of insect, and plot wise evenness were high in $R$. serpentina (Shannon index: 2.73, evenness: 2.01). The Shannon index was low in $U$. dioca (2.42). The inverse Simpson and evenness index were low in $V$. jatamansii (2.15 and 1.75 respectively). This attributes that assemblage of insect vary with the physiological and morphological adaptability with these plant species (Pegadaraju et al. 2005, Belete 2018). The taxonomic distinctness (delta + ) versus generic number of insects in these medicinal plants showed high variation which probably is link with the differential preference of insect type to host plants as usually expected in many cases. There were wider taxonomic groups associated with some plants but in most of the cases higher species number and low taxonomic distinctness were observed indicating insect communities were strongly sensitive for the fitness with host plant types (Agosta 2006, Denno 2012). There was negative effect of temperature and humidity in all seasonal data for the abundance and diversity of insect. Local temperature, humidity and other microclimatic factors favours the insect plant interaction and assemblage of particular insect species to the particular host plant (Bale et al. 2002). Physical parameters, soil chemistry and texture, temperature, relative humidity as well as weed invasion status further favour the assemblage of many insect species (Collins 2005). Therefore, the accumulation of insect species in the particular medicinal plants depends upon the microhabitat and other bioclimatic parameters beside the resistivity of particular host plant types. In our indicator species analysis, the maximum species were classified in Mentha spicata whereas different situation were observed in different medicinal plants in different geographic region. It was reported by Ramanna et al. (2010) that observed eleven species of phytophagous pests on Ashwagandha with occurrence of high number of hemiptera and low lepidopteran in India. Likewise, the study resembles with Bonjo et al. (2006), who found different order including diptera, hymenoptera, coleoptera, orthoptera, lepidoptera and homoptera in two Ocimum species but reveled the abundance of dictyoptera, isopteran and hymenoptera.

A detail study of insect pest on medicinal plants should be done in different ecological zones of Nepal especially focusing the natural condition as well as cultivation sites. Limited work has been done in context of Nepal on insect specifically on medicinal plants. Department of Plant Resource (DoPR 2015) reported stem borer on Swertia chirayita. Similarly they obtained recorded black aphid (Aphis fabae) and psyllid (Diaphorina citri) on Zanthoxylum armatum in these medically important plants. Jasyal and Uniyal (2003) reported caterpillar, leaf folder, liligreen caterpillar, green caterpillar, aphids, white grub and aphids were found to feed on various medicinal plants like Sarphagandha (Rauvolfia serpentina), Ashwagandha (Withania somnifera), Isabgol (Plantgo ovate), Chandrasur (Lepidium sativum), Rossa grass (Cymbopogon martini) in South India. Sharma et al. (2014) recorded fifteen insect pest species belonging to four orders that are associated with ten medicinal plants in different parts of Himachal Pradesh of Northern India. Seven insect species Henosepilachna vigintioctopunctata, Nezara viridula, Dysdercus cingulatus, Helicoverpa armigera, Drosicha mangiferae, chrysomelid (Podagrica bowringi) Baly and one unidentified pentatomid bug were reported on Withania somnifera. The study resembled to Chadha (2001) who reported Epilachna beetle, bug, aphid and grasshopper on medicinal plant Ravolfia serpentina. It is also similar to Department of Plants Resource (DoPR 2015) which recorded Aphis species on Zanthoxylum armatum from Nepal. Occurrence of Coccinella septumpuctata on medicinal plants is in consistent to Abro et al. (2016) who also reported different predatory 
Assemblage of insects on medicinal plants: an insight from ICIMOD herbal garden...

Coccinilla septempunctata. Similarly, this study is similar to Tara et al. (2011) who conclude the occurrence of Monolepta and Pentatomid in Zanthoxylum armatum.

\section{CONCLUSION}

Microclimate is important for the diversity and abundance of insect fauna associated with medically important plants. Some of them are specific to particular host plant attributing as indicator species for those medicinal plants. Further species level study is necessary to reach into a more realistic conclusion especially for indicator and pest species. Similarly, detail microclimatic characteristics should be explored while planning a large scale cultivation of medicinal plants in different eco-regions of Nepal. To find the insect interaction (positive and negative) under different taxonomic line with these host plants, a further study is needed with large scale data. This study will be the base line information about pest and non pest insect associate with medically important plants. Investigation of more covariates is essential to find the underling mechanism about the species fluctuation with season, temperature and humidity for long term monitoring of insect pest associated with medicinally important plants in Nepal.

\section{ACKNOWLEDGEMENTS}

Authors are thankful to International Centre for Integrated Mountain Development (ICIMOD), Nepal for providing the herbal garden for this study and are grateful to the authorities of Natural History Museum, Tribhuvan University and Nepal Agriculture research Council, Khumaltar, Kathmandu for providing the voucher specimens to compare with our collected insects during identification process.

\section{REFERENCES}

Abro, G.H., Syed, T.S., Khanzada, M.S., Khanzada, S.R., Salman, M. and Anwar, S. 2016. Arthropods associated with some medicinal plants under field conditions in Sindh province of Pakistan. Journal of Entomology and Zoology Studies 4(1): 516-520.

Agosta, S.J. 2006. On ecological fitting, plant-insect associations, herbivore host shifts and host plant selection. Oikos 114(3): 556-565.

Arya, M.K., Tamta, P. and Dayakrishna. 2016. Study on distribution and diversity of beetles (Insecta: Coleoptera) in different elevational zones of Binsar wildlife sanctuary. Almora, Uttarakhand, India. Journal of Entomology and Zoology Studies 4(4): 311-316.

Balakrishnan, S., Srinivasan, M. and Mohanraj, J. 2014. Diversity of some insect fauna in different coastal habitats of Tamil Nadu, southeast coast of India. Journal of Asia-Pacific Biodiversity 7: 408-414.
Bale, J.S., Masters, G.J., Hodkinson, I.D., Awmack, C., Bezemer, T.M., Brown, V.K. and Good, J.E. 2002. Herbivory in global climate change research: direct effects of rising temperature on insect herbivores. Global Change Biology 8(1): 1-16.

Baral, S.R. and Kurmi, P.P. 2006. A compendium of medicinal plants in Nepal. IUCN The World Conservation Union.

Belete, T. 2018. Defense mechanisms of plants to insect pests: from morphological to biochemical approach. Trends in Technical \& Scientific Research 2(2): 555584.

Belskaya, E.A. and Kolesnikova, A.A. 2011. Species composition and ecological characteristic of Rove Bettle (Coleoptera, Staphylinidae) in the southern Taiga of middle Urals. Entomological Review 9(5): 123-137.

Bonjo, A.D., Lawal, O.A. and Aina, S.A. 2006. Insect diversity of two medicinal Labiatae in south western Nigeria. Journal of Entomology 3(4): 298-304.

Chadha, K.L. 2001. Diseases and pest management: medicinal plants in hand book of horticulture. Indian Council of Agriculture Research, New Delhi, pp. 839-842.

Clarke, K.R. and Warwick, R.M.1999. The taxonomic distinctness measure of biodiversity: weighting of step lengths between hierarchical levels. Marine Ecology Progress Series 184: 21-29.

Collins, A. R. 2005. Implications of plant diversity and soil chemical properties for cogongrass (Imperata cylindrica) invasion in northwest Florida. $\mathrm{PhD}$ thesis, University of Florida..

David, B.V. and Ananthakrishnan, T.N. 2006. General and applied entomology. $2^{\text {nd }}$ edition. Tata McGrawHill publishing Company Limited, New Delhi, India.

Denno, R. (Ed.). 2012. Variable plants and herbivores in natural and managed systems. Elsevier.

DoPR. 2015. Pest list of five most traded medicinal and aromatic plants of Nepal. Department of Plant Resources, Thapathali, Kathmandu, Nepal.

Gillote, C. 2005. Entomology. Springer publication.

Gupta, D. and Bhusal, D. 2018. Response of soil nematodes under different pest management practices: a field experimental approach in Tomato (Lycopersicon Esculentum L.) growing agroecosystem. Journal of Institute of Science and Technology 22(2): 45-55. 
Hill, D.S. 1993. Agricultural insect pests of the tropics and their control. $2^{\text {nd }}$ ed., Cambridge University Press.

Jasyal, G.S. and Uniyal, M. 2003. Aushadhi padapo ka vyavasayik krishikaran. Indian Society Agriculture. Business, Professional Publication, New Delhi.

Najar, I.A. and Bashir, A. 2016. Insect diversity of Doodhpathri (Budgam), Jammu and Kashmir, India. International Journal of Fauna and Biological Studies 3(6): 28-32.

Pegadaraju, V., Knepper, C., Reese, J. and Shah, J. 2005. Premature leaf senescence modulated by the Arabidopsis phytoalexin deficient 4 gene is associated with defense against the phloem-feeding green peach aphid. Plant physiology 139(4): 19271934.

Ramanna, D., Prasad, K. and Goud, K.B. 2010. Pest complex of medicinal plants. Karnataka Journal of Agricultural Sciences 23(1): 197-199.

Richards, O.W. and Davies, R.G. 2013. IMMS' general textbook of entomology. $10^{\text {th }}$ ed., volume 2: Classification and Biology. Rakmo Press, New Delhi.

Sharma, M., Budha, P. and Pradhan, S. 2015. Efficacy test of bio-pesticides against tobacco whitefly Bemisia tabaci (Gennadius, 1889) on tomato plants in Nepal. Journal of Institute of Science and Technology 20(2): 11-17.

Sharma, P.C., Kumar, A., Mehta, P.K. and Singh, R. 2014. Survey studies on insect-pests associated with important medicinal plants in Himachal Pradesh. Indian Journal of Scientific Research and Technology 2(4): 2-7.

Stubbs, A.E. and Falk, S.J. 1983. British Hoverflies. An illustrated identification guide. British Entomological and Natural History Society.

Subedi, B.P. 1997. Utilization of non-timber forest products: Issues and strategies for environmental conservation and economic development. Workshop on "The Utilization of NTFPs for Environmental Conservation and Economic Development in Nepal”, Asia Network for Small Scale Bioresources (ANSAB), 29 March 1997, Kathmandu, Nepal.

Tara, J.S., Sudan, M. and Sharma, B. 2011. A report on the occurrence of insect pests on Zanthoxylum armatum DC (Family: Rutaceae), an important medicinal plant in Jammu region. Journal of Life Sciences 6(2): 223-228.

Thapa, V.K. 2015. Insect diversity in Nepal. VK Thapa, Nepal. 